\title{
Demodectic mange in Iraqi camels
}

M. H. Hussain

Coll. of Vet. Med.

Univ.of Al-Qadissiya
F. G. Habasha

Coll. of Vet. Med.

Univ.of Baghdad
M. K. Faraj

Coll. of Vet. Med.

Univ.of Baghdad

\section{Abstract}

The survey began in December 2008 \& finished in June 2009 in three governorates; AlQadissiya, Al-Najaf \& Al-Muthanna in different locations inspecting 2412 dromedaries, we found 55 affected camels with demodectic mange, samples were carried out to detect the mange, they present $2.3 \%$ of the total inspected camels. Demodectic mange was diagnosed in $58.2 \%$ of camels ranged in 5-10 years old \& $16.4 \%$ of camels more than 10 years old \& $25.4 \%$ in camels less than 5 years old which indicate the high incidence in camels aged in 5-10 years.

\section{Introduction}

Camelids, like other livestock, are exposed to and affected by a range of ectoparasites, which may directly or indirectly cause a great diversity of health problems. Some ectoparasites play a significant role in many disorders. For example, some biting insects are vectors of disease agents such as Trypanosoma evansi, and the mite Sarcoptes scabiei that is the cause of sarcoptic mange. Both are regarded as the most two economically important diseases in camelids, the latter especially in Peru, which has the largest New World Camel (NWC) population (1). The ectoparasites of camelids can be classified into two zoological classes, the Arachnea and the Insectea, both are within the phylum Arthropoda (2).Sarcoptic mange is regarded as one of the most prevalent and serious camel diseases $(3 ; 4)$. It is often ranked second in importance to all the disorders in dromedary camels (5), and second only to trypanosomosis. It can be generally regarded as a chronic debilitating condition with high morbidity and low mortality. The infection is also common among NWC (6). The disease "sarna sarcoptica" was previously widespread in North American captive camelids where it appears to be decreasing, probably through routine deworming with ivermectin (7).Any camelid regardless of sex and age may be affected by S. scabiei (8). However, some reports state that the infection is more prevalent in younger animals (9). It is often cited that animals in poor condition are more prone to infection (3; 10). However, this is controversial as others report that animals in a very good condition can also become infected
(8).There are conflicting opinions regarding the seasonality of the disease. Some authors describe a quiescent phase usually coinciding with winter (5), others finding a higher incidence in the winter $(3 ; 9 ; 8),(10)$ hand found a higher prevalence in Saudi Arabia during the hot summer months.(11) had found sarcoptic mange which was endemic in Al-Najaf governorate in Iraq with $25.9 \%$ percentage. The main sites of lesions in examined camels were neck, head, and dorsum respectively with no lesion on the hump. No relation was detected between the infection and the sex, but young dromedaries were more susceptible to infection.Psoroptic mange mites spend their entire life on the skin, feeding superficially. They reportedly infest camelids, but are less commonly found on camelids than S.scabiei. It was recently shown that Psoroptes $s p$. isolates of different phenotypes, hosts and geographic origins are nonspecific $(12 ; 13)$ recorded the only documented case of psoroptic mange in dromedaries and (14) in Bactrians in Mongolia. In many countries sarcoptic and psoroptic mange are reportable diseases.Infestation with Chorioptes is most probably rare in camels. It has been reported on a Bactrian camel (10) and in the Netherlands on one llama, three alpacas and two camels, one of which had"foot mange" (15). An infestation of Chorioptes sp. was also responsible for mange in a herd of alpacas from Chile recently imported into France (16).The preferred site of the burrowing mite of the genus Demodex is at the hair follicles and sebaceous glands of the skin. It is a cigar- shaped, elongated $0.2 \mathrm{~mm}$ long mite. The mite is most probably 
transmitted from the dam to the offspring during nursing. Demodex sp. is found in all domestic mammals and humans worldwide. Most of the species are named after their hosts, i.e. D. canis, D. bovis etc. These follicular mites mainly live as commensals in the skin. In some animals, these mites may cause mange, of particular severity in dogs. In bovines, the most significant sequela to infestation is the damage to the hides, causing economic loss (2).Demodex $\mathrm{sp}$. has been reported on dromedaries in Iran where the eyelids of $15 \%$ of the camels were infested (17). There was no evidence of any secondary bacterial infection in the investigated camels, nor were there any significant histological changes other than distention of the hair follicles. Demodex $\mathrm{sp}$. was isolated from camels exhibiting mange on a ranch in Kenya (18). Demodex sp. commonly occurs in llamas and alpacas in Bolivia (19). The mite most probably also infests other NWC in other countries.It is a very specialized group of parasitic mites which live in the hair follicles and sebaceous glands of various mammals causing demodectic or follicular mange. The parasites which occur on different species, although it is difficult to distinguish between them morphologically, since the main differences are that of size. Most of the species are called after their host, for instance; D. canis, D. camali, D. bovis etc (20).

\section{I-Materials}

Blades

Centrifuge

Digital Camera

Ethanol $96 \%$

Light microscope

II- Animals of the study

Three governorates were involved in this research; Al-Qadissiya, Al-Najaf and Al-Muthanna, samples collected from the slaughter houses, sale yards and the herds found in several locations randomly. The research began on December 2008 and finished on June 2009. 2412 Iraqi dromedaries were examined regardless to location, age, sex and breed, from which 55 camels were suffering demodectic mange.

III- Diagnosis of Demodectic mange

Skin was thickened, white to gray heavy crusts with moist dermis beneath, complete hair loss and itching. Direct microscopic examination of skin scrapings is the best way to diagnose mange, clipping the area with a no. 40 blade before scraping enables better visualization of the lesion and

\section{Results \& discussion}

Potassium hydroxide sol. $10 \%$

Screw cab containers

Sodium hydroxide sol. $10 \%$

Water bath

removes excess hair that impedes proper scraping and interferes with collection of epidermal debris, deep skin scrapings (until capillary blood oozing) were collected from 55 suspected camels using sterile scalpel blades no. 10, the scalpel blade should be held between the thumb and the second finger, the first finger to press and prevent cutting the skin. Average area scraped should be $6-8 \mathrm{~cm}^{2}$. Collect the scrapings in screw cab containers and preserve in adequate amount of $10 \%$ potassium hydroxide or Sodium hydroxide. In the laboratory, the samples heated until the solution became homogenized and left to be cool, centrifuged at $1500 \mathrm{rpm}$ for 5 minutes, a drop of the feculence is examined on the slide microscopically (21).
55 dromedaries from different ages and sexes have been sampled by skin scrapings to find out the demodectic mange, most of the cases in which skin is thickened, white to gray heavy crusts with moist dermis beneath, complete hair loss and itching. Skin scrapings preserved in $10 \%$ potassium hydroxide or $10 \%$ sodium hydroxide, dispatched to the laboratory in which microscopic examination showed the demodex mites, It is a cigar-shaped elongated as tall as having eggs, the thorax has four obscure pairs of short stumpy legs showed in fig (1), lesions are common on 


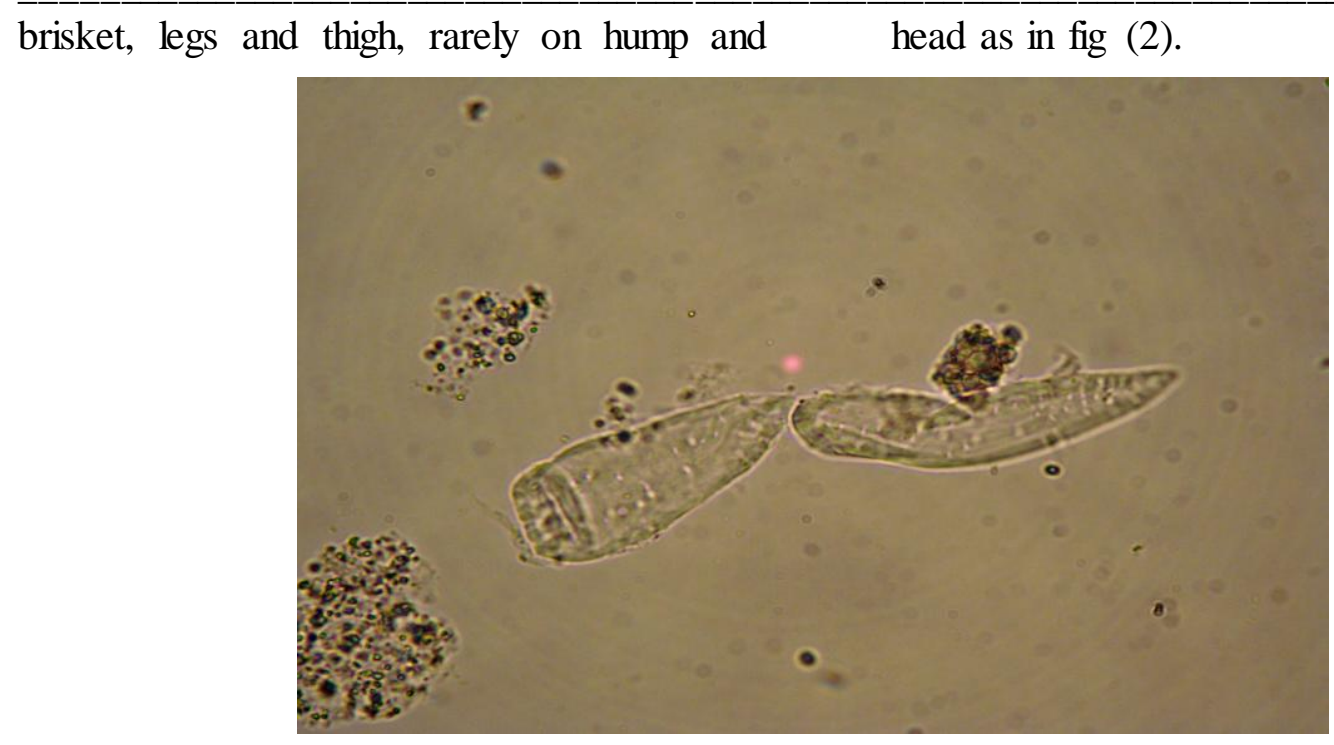

Fig (1): Demodex mite from skin of camel infected with demodectic mange. X100

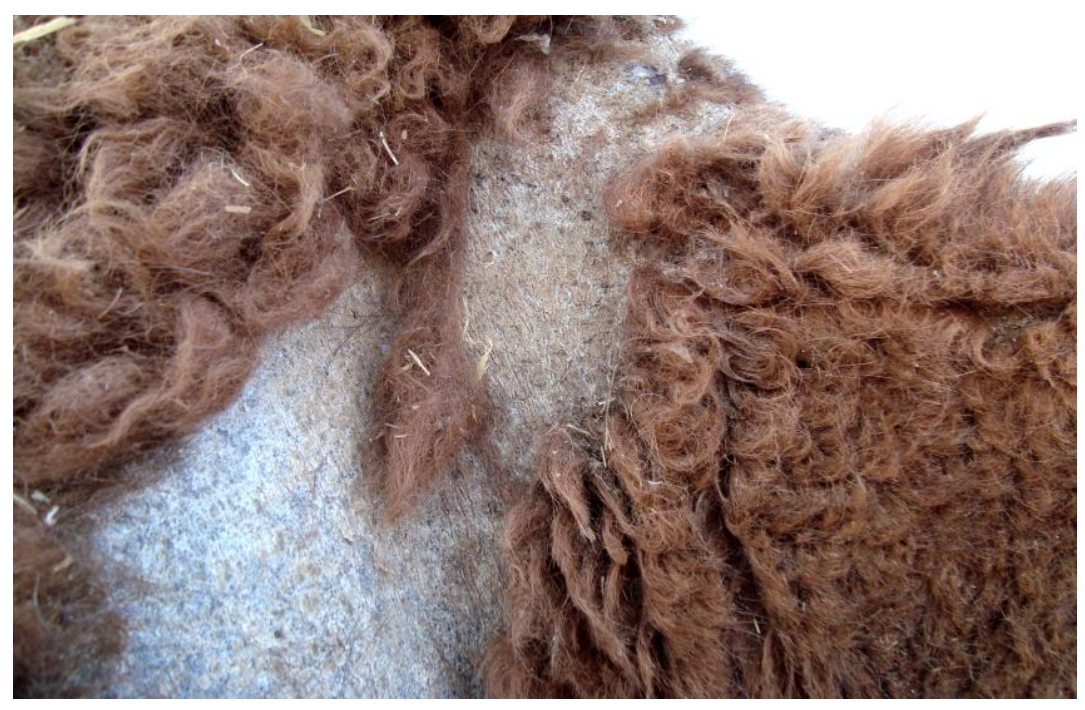

Fig (2): Demodectic mange on the shoulder in six years camel

General camel attitude ranged in $(36.3 \pm 0.03) \quad \mathrm{C}^{\circ}$ in temperature, $(15 \pm 0.5)$ respiratory rate, and $(45 \pm 1.5)$ pulse rate. Complete hair loss, itching, and no lamness when infection sink on the legs, upset, slight decrease in appetite and rumination, pink mucous membrane and some of affected camels have respiratory disorders and /or diarrhea.Table (1) shows that all ages are involved in infestation with demodectic mange but more commonly in camels in 510 years and that may be due to the high percentage of these camels in the herds which may reach to $70 \%$ according to this survey. Both sexes have the similar percentage of infestation in regard to the absence of the disease in females more than 10 years old which may be occasional. The first report developed on mange in camels in Iraq was by (22) detecting Sarcoptes scabiei, (11) has reported Sarcoptic mange in AlNajaf governorate. Other types of mange had reported in camels in other countries. (23) considers Sarcoptic mange, due to Sarcoptes scabiei var cameli, to be the most important ectoparasitism in Arabian camels which had already reported in Iraq. 
Table (1): Numbers of infected camels with Demodectic mange according to the location, age and sex

\begin{tabular}{|c|c|c|c|c|c|c|c|c|}
\hline \multirow{2}{*}{\multicolumn{2}{|c|}{ Location }} & \multirow{3}{*}{$\begin{array}{l}\text { Infected } \\
\text { camels } \\
6\end{array}$} & \multicolumn{2}{|c|}{$\sim 5$ years } & \multicolumn{2}{|c|}{ 5-10 years } & \multicolumn{2}{|c|}{$10 \sim$ years } \\
\hline & & & \multirow{2}{*}{\begin{tabular}{|l|} 
male \\
1
\end{tabular}} & \multirow{2}{*}{$\begin{array}{l}\text { female } \\
0\end{array}$} & \multirow{2}{*}{\begin{tabular}{|l|} 
male \\
2
\end{tabular}} & \multirow{2}{*}{$\frac{f \text { female }}{2}$} & \multirow{2}{*}{$\begin{array}{l}\text { male } \\
1\end{array}$} & \multirow{2}{*}{$\begin{array}{l}\text { Female } \\
0\end{array}$} \\
\hline \multirow{6}{*}{ Al-Qadissyia } & Slaughter house & & & & & & & \\
\hline & $\begin{array}{l}\text { Al-Hamza Al- } \\
\text { Shargy }\end{array}$ & 4 & 0 & 0 & 4 & 0 & 0 & 0 \\
\hline & Al-Daghara & 0 & 0 & 0 & 0 & 0 & 0 & 0 \\
\hline & Aal-Bdeer & 4 & 0 & 0 & 0 & 2 & 2 & 0 \\
\hline & Al-Shaf'ya & 0 & 0 & 0 & 0 & 0 & 0 & 0 \\
\hline & Al-Shenafe ya & 5 & 1 & 1 & 1 & 2 & 0 & 0 \\
\hline \multirow{2}{*}{ Al-Najaf } & Slaughter house & 9 & 0 & 0 & 3 & 3 & 3 & 0 \\
\hline & Sale yard & 3 & 2 & 0 & 1 & 0 & 0 & 0 \\
\hline \multirow{3}{*}{ Al-Muthanna } & Slaughter house & 4 & 0 & 0 & 3 & 1 & 0 & 0 \\
\hline & Sale yard & 8 & 0 & 3 & 0 & 5 & 0 & 0 \\
\hline & Herds & 12 & 3 & 3 & 3 & 0 & 3 & 0 \\
\hline \multicolumn{2}{|l|}{ Total } & 55 & 7 & 7 & 17 & 15 & 9 & 0 \\
\hline \multicolumn{2}{|l|}{ Percentage } & & 12.7 & 12.7 & 30.9 & 27.3 & 16.4 & 0 \\
\hline \multicolumn{2}{|l|}{ Total } & & \multicolumn{2}{|l|}{14} & \multicolumn{2}{|l|}{32} & \multicolumn{2}{|l|}{9} \\
\hline \multicolumn{2}{|l|}{ Percentage } & & \multicolumn{2}{|l|}{25.4} & \multicolumn{2}{|l|}{58.2} & \multicolumn{2}{|l|}{16.4} \\
\hline
\end{tabular}

It seems that Iraqi camels are susceptible to be infected by Sarcoptic and Demodectic mites. Several authors; (2); (3); (4); (5) and (6); consider the mange as the second important disease in camels after trypanosomosis due to its rapid spread and the severe effect on camels' behavior which seemed upset and itching especially when infested by Sarcoptic mites. Consequently, owners are very interested in treating even when using non- medical therapies. This type of mange may be transmitted between dogs and camels that already domesticated together. The fallen percentage of infestation with mange may belong to the emergence of the recent broad spectrum acaricides which are effective against many external (e.g. mites and ticks) and internal (e.g. nematodes and cestodes) parasites in the same time.

\section{References}

1. Alvarado, J.; Astrom, R.G. and Heath, G.B.S. (1966). An investigation into remedies of sarna (sarcoptic mange) of alpacas in Peuro. Expl. Agric. 2: 245-254.

2. Wernery, U.; \& Kaaden, O.R. (2002). Infectious diseases in camelids, $2^{\text {nd }}$ revised \& enlarged edition. Blackwell Wissenschafts-Verlag $\mathrm{GmbH}$ Kurfiirstendamm 57,10707 Berlin.

3. Lodha, K.R. (1966). Studies on sarcoptic mange in camels (Camelus drornedarius). Vet. Rec. 79:4143.

4. Higgins, A.J. (1983). Observations on the diseases of the Arabian camel (Camelus dromedarius) \& their control (A review). Vet. Bull. 53:

5. Pegram, R.G.; \& Higgins, A.J. (1992). Camel ectoparasites: a review. In:
W.R. Allen, A.J. Higgins, I.G. Mayhew, D.H. Snow \& J.F. Wade (eds.): Proceedings of the lst Camel Conference. R. \& W. Publications, Newmarket, UK, pp. 69-82.

6. Fowler, M.E. (1998). Medicine \& surgery of South American Camelids. Iowa State University Press, Ames. USA.

7. Rosychuk, R.A.W. (1989). Llama dermatology. Vet. Clin. North Am. Food Anim. Pract. 5: 203- 215

8. Nayel, N.M.; \& Abu-Samra, M.T. (1986). Sarcoptic mange in the onehumped camel (Camelus dromedarius). A clinicopathological \& epizootiological study of the disease \& its treatment. 1. Arid Environm. 10: 199-211.

9. Rathore, M.S.; \& Lodha, K.R. (1973). Observation on sarcoptic mange in 
camels (Camelus dromedarius). Indian Vet. J. 50: 1083-1088.

10. Higgins, A.J. (1986). Common ectoparasites of the camel \& their control. In: A.J. Higgins (ed.): The Camel in Health \& Disease. Bailli\&re, Tindall \& Cox, London.

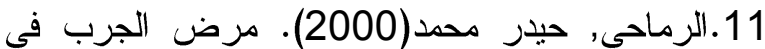

آلجمال العربية في محافظة النجف, دراسة

مسحية وعلاجية. رسالة ماجسنتير - جامعة لإليفة

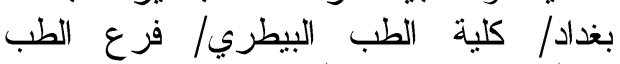

$$
\text { الباطني و الوقائي البيطري. }
$$

12. Zahler, M.; Essig, A.; Gothe, R.; \& Rinder, H. (1998). Genetic evidence suggests that Psoroptes isolates of different phenotypes, host \& geographic origins are conspecific. Int. 1. Parusitol. 28: 1713-1719.

13. Gabaj, M.M.; Beesley, W.N.; \& Awan, M.A.Q.(1992). A survey of mites on farm animals in Libya. Ann. Trop. Med. Parasitol. 86: 537-542.

14. Werner, G.; Porsch, G.; Ilchmann, G.; \& Hiepe, Th. (1989). Exploratory studies on the efficacy of Bayticol Pour-on in sheep, cattle \& camels in the People's Republic of Mongolia. Vet. Med. Rev. 60: 40-42.

15. Cremers, H.J.M. (1984). The incidence of Chorioptes bovis (Acarina; Psoroptidae) in domesticated ungulates. Trop. Geogr. Med. 36: 105.

16. Petrowski, M. (1998). Chorioptic mange in an alpaca herd. In: Kwochka, K.W., T. Willemse \& C. von Tscharner (eds.): Advances in veterinary dermatology. Vol. 3 . Proceedings of the Third World Congress on Veterina $\mathrm{y}$ Dermatology. Edinburgh, Scotl\&, 11-14 Sept. 1996. 450-451.

17. Rak, H.; \& Rahgozar, R. (1975). Demodectic mange in the eyelid of domestic ruminants in Iran. Bull. SOC. Pathol. Exot. 68: 591-593.

18. Bomstein, S. (1995). Skin diseases of camels in: Camel keeping in Kenya. Ed. Evans, J.O., S. Piers Simpkin \& D.J. Atkins. Range Manugment H\&book of Kenya 3 (8): 7-13.

19. Sqire, F.A. 1972. Entomological problems in Bolivia. PANS. 18: 249-268.

20. Soulsby, E.J.L.(1974). Helminths, Arthropods \& protozoa of domesticated animals, Aracchnida (phylum Arthropoda) $6^{\text {th }}$ ed.. Williams 7 Wilkins company, Baltimore, United States.

21. Charles, M. \& Robinson, E. (2006). Diagnostic parasitology for veterinary technicians. Diagnosis of parasitism of the skin. 3rd edition, Mosby Elsevier. China.

22. Leiper, J. W. G., (1957). Animal parasites and their control, report to the government of Iraq. FAO. Rome, No.:610.

23. Al-Ani, F. K., (2004). Camel management and diseases. $1^{\text {st }}$ ed. Al-Shraq printing press and Dar Ammar book publisher, Jordan.

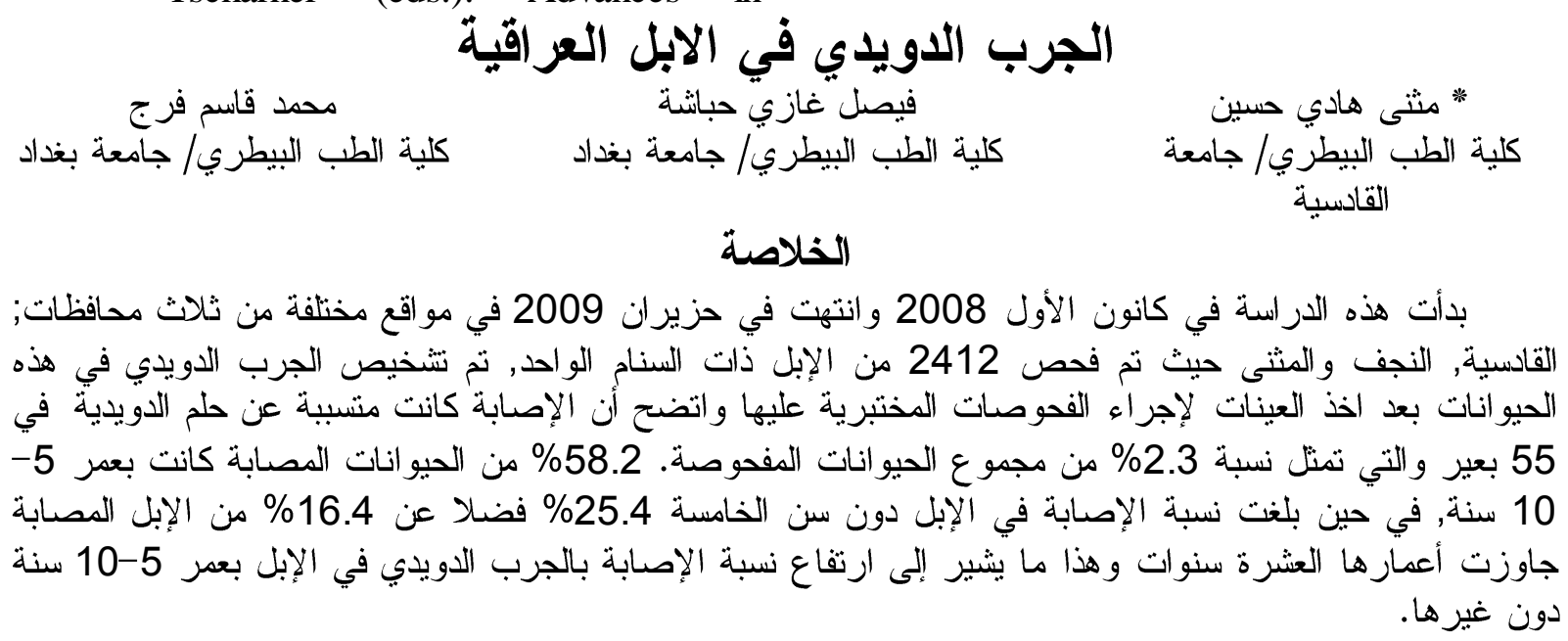

الخلاصة

بدأت هذه الدراسة في كانون الأول 2008 و انتهت في حزيران 2412 فئة 2009 في مواقع مختلفة من ثلاث محافظات;

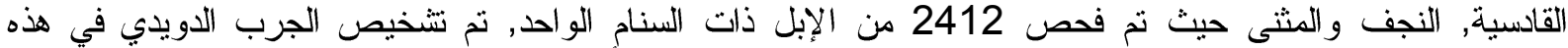
الحيوانات بعد اخذ العينات لإجراء الفحوصات المختبرية عليها واتضح أن الإصلابة كانت متسببة عن حلم الدويدية في

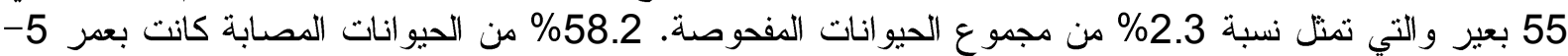

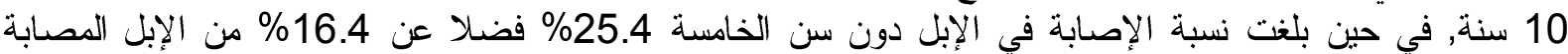

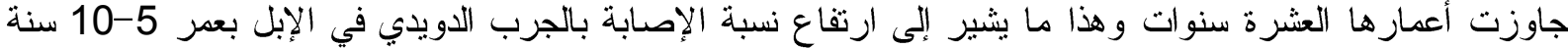

